\title{
DAMPAK FLUKTUASI SUHU PERMUKAAN LAUT TERHADAP KEMATIAN KARANG DI PERAIRAN PULAU WEH, INDONESIA
}

\section{THE IMPACT OF SEA SURFACE TEMPERATURE FLUCTUATION ON CORAL MORTALITY IN WEH ISLAND COASTAL WATERS, INDONESIA}

\author{
Ulung Jantama Wisha, Try Al Tanto, Nia Naelul Hasanah Ridwan \& Ruzana Dhiauddin \\ Loka Riset Sumber Daya dan Kerentanan Pesisir, BRSDMKP, KKP \\ e-mail : ulungjantama@gmail.com \\ Diterima tanggal: 26 Juni 2018 ; diterima setelah perbaikan: 08 Agustus 2019 ; Disetujui tanggal: 25 Agustus 2019 \\ DOI: http://dx.doi.org/10.15578/jkn.v14i2.6979
}

\begin{abstract}
ABSTRAK
Pulau Weh merupakan salah satu pulau terluar yang menjadi wilayah yang sangat penting di Indonesia sebagai pusat kawasan maritim, dipengaruhi oleh kondisi dipole mode di Samudera Hindia dan beberapa lautan seperti Laut Andaman dan Selat Malaka. Pada waktu tertentu terjadi anomali suhu yang berubah drastis yang menyebabkan tingginya level kematian karang yang diawali dengan kejadian bleaching. Studi ini bertujuan untuk mengidentifikasi kematian karang disebabkan oleh anomali suhu yang dibangkitkan oleh Indian Ocean Dipole (IOD) dan faktor antropogenik. Suhu permukaan laut regional dianalisis secara spasial dan statistik dalam bentuk data deret waktu. Metode Line Intercept Transect (LIT) untuk menilai tutupan dan kondisi karang dalam bentuk persen tutupan, indeks mortalitas, dan juga dokumentasi pemutihan karang, yang dilakukan di tiga (3) stasiun observasi (Keunekai, Ie Meulee, dan Batee Glah). Selama 5 tahun, tren suhu meningkat sebesar \pm 3 0C karena kondisi dipole mode sepanjang tahun. Pada Tahun 2016, dipole mode menunjukkan nilai negatif yang menyebabkan suhu hangat melalui Laut Andaman dan berdampak pada perairan Pulau Weh. ENSO memiliki peran dalam mendukung sebaran suhu yang lebih tinggi di pesisir barat Sumatera. Persen tutupan karang pada tiga (3) stasiun observasi mencapai 9,1 \%, 34,4 \%, dan 14,7 \% yang dikategorikan buruk hingga sedang. Berdasarkan perhitungan indeks mortalitas, dikategorikan tinggi hingga sangat tinggi. Dampak paling berbahaya adalah kejadian bleaching yang sangat mengkhawatirkan di perairan Keunekai dan Batee Glah, mengindikasikan bahwa karang telah terancam oleh degradasi suhu.
\end{abstract}

Kata Kunci: Flutuasi suhu permukaan laut, Kematian karang, Pulau Weh, Indian Ocean Dipole.

\begin{abstract}
Weh Island is one of the outer most islands which is tremendously significant in Indonesia as the center of maritime, influenced by dipole mode condition in the Indian Ocean and several seas such as Andaman Sea and Malacca Strait. At certain times, a dramatic temperature anomaly occurred, inducing the high rate of coral mortality that started with bleaching event. This study aims to identify the demised coral due to temperature anomaly, evoked by Indian Ocean Dipole (IOD) and anthropogenic factors. Regional sea surface temperature data were analyzed spatially and statistically in the form of time series data. Line Intercept Transect (LIT) method was employed to assess the percent cover, mortality index, and bleaching documentation as well, which was done in the three observation stations (Keunekai, Ie Meulee, and Batee Glah). For 5 years, the temperature trend increased $\pm 3{ }^{\circ} \mathrm{C}$ because of the dipole mode condition occurred throughout the year. In 2016, the dipole mode was negative inducing the warm temperature through Andaman Sea that impacts on the Weh Island waters. ENSO plays a role in supporting the higher temperature distribution in the west coast of Sumatera. The percentage of coral cover in the three observation stations reached $9.1 \%, 34.4 \%$, and $14.7 \%$ respectively, categorized into poor to moderate. Based on mortality index calculation, the coral mortality can be categorized into high to very high of mortality. The most pernicious impact is characterized by bleaching occurrence that is very alarming in the Keunekai and Batee Glah waters, indicating that the coral has been threatened by SST degradation.
\end{abstract}

Keywords: Sea temperature fluctuation, Coral mortality, Weh Island, Indian Ocean Dipole. 


\section{PENDAHULUAN}

Pulau Weh merupakan salah satu pulau terluar di Indonesia, dimana secara langsung berbatasan dengan Samudera Hindia. Sirkulasi air di sekitar Pulau Weh dipengaruhi oleh proses-proses yang terjadi di Samudera Hindia seperti siklus monsoon, Indian Ocean Dipole (IOD), dan Maiden Julian Oscillation (MJO). Faktor-faktor tersebut mengendalikan suhu permukaan laut, evaporasi, dan curah hujan di wilayah barat Pulau Sumatera dan sekitarnya (Wisha et al., 2017). Akhirnya, hal tersebut berdampak pada degradasi kondisi lingkungan seperti kematian ikan dan karang. Pulau Weh menjadi daerah yang penting untuk perikanan budidaya maupun wisata bahari, namun kondisi perairan yang tidak stabil akan menghambat tercapainya tujuan tersebut.

Terumbu karang secara luas berguna untuk bioindikator (mengidentifikasi kondisi dan proses biogeokimia), sebagai pemecah ombak alami (perlindungan pantai), dan mendukung sumber daya perikanan, serta mendukung aktivitas wisata bahari (Burke et al., 2002). Terumbu karang di Aceh bagian utara dan sekitarnya terkenal dengan spesies terumbu datar yang hidup diperairan dangkal, yang didominasi oleh spesies karang massive (Poritidae dan Faviidae) dan spesies karang branching (Acropora dan Montipora) (Hagan, 2007). Secara umum, terumbu karang Pulau Weh lebih baik kondisinya bila dibandingkan dengan terumbu karang didekat pesisir Aceh, terutama untuk tipe karang keras (hard coral), hal tersebut dikarenakan adanya perbedaan pengelolaan dimasa lampau (Campbell et al., 2007).

Pemutihan karang adalah respons terkait stres yang dapat dipicu oleh peningkatan suhu permukaan laut (SST), masalah pengasaman laut, dan degradasi kualitas air. Peningkatan frekuensi pemutihan karang baru-baru ini telah menyebabkan kekhawatiran bahwa peningkatan suhu laut dapat mengancam seluruh wilayah terumbu karang. Kenaikan SST regional sebesar $0.1{ }^{\circ} \mathrm{C}$ menghasilkan peningkatan $35 \%$ dan $42 \%$ pada intensitas pemutihan karang secara geografis (McWilliams et al., 2005). Pemutihan karang adalah kematian karang akibat hilangnya ganggang simbiotik dan/atau pigmennya, merupakan respons yang dapat dipicu oleh berbagai tekanan yang bekerja pada skala lokal. Tekanan ini meliputi radiasi matahari, anomali salinitas, sedimentasi, penyakit, dan kenaikan suhu (Baird et al., 2009).

Dua osilasi iklim El Nino Southern Oscillation (ENSO) dan Indian Ocean Dipole (IOD) memainkan peran besar dalam menghasilkan anomali atmosfer laut di Pasifik dan Samudra Hindia yang juga bertanggung jawab atas fenomena pemutihan karang. IOD adalah fenomena yang terjadi antara atmosfer dan samudra, ditandai oleh perbedaan anomali suhu permukaan "dua-kutub" di wilayah tropis Samudera Hindia timur (perairan Indonesia di sekitar Sumatra bagian barat dan selatan) dan di Samudra Hindia barat (pantai timur benua Afrika) (Yamagata et al., 2000). Indeks Dipole Mode (DM) didefinisikan sebagai perbedaan anomali suhu permukaan laut darigaris lintang $10^{\circ} \mathrm{S}$-khatulistiwa dan bujur $90^{\circ}-110^{\circ} \mathrm{E}$ atau Samudra Hindia khatulistiwa ke arah timur dan lintang $10^{\circ} \mathrm{S}-10^{\circ} \mathrm{LU}$ dan bujur $50^{\circ}$ $70^{\circ} \mathrm{E}$ atau bagian barat dari Equatorial Samudra Hindia (Saji et al., 1999). Nilai indeks DM $>0,35$ diklasifikasikan sebagai IOD $(+)$ dan DM $<-0.35$ diklasifikasikan sebagai IOD (-). IOD (+) berarti bahwa suhu permukaan laut di pantai timur Afrika lebih tinggi daripada di pantai barat Sumatera, sebaliknya adalah IOD (-) dimana fase hangat terjadi di pantai barat Sumatera, terjadi penigkatan konveksi (Schott et al., 2009). Anomali suhu permukaan laut (SSTa) selama fase positif IOD ditandai oleh air dingin di perairan timur Samudra Hindia dan air hangat di barat. SSTa terjadi di dekat pantai selatan Jawa dan Sumatra bagian barat dan menurun dalam jangka panjang sekitar \pm 3 0C (Saji et al., 1999; Du et al., 2008; Yuan et al., 2008). Sejumlah penelitian yang sebelumnya telah dilakukan untuk menilai kondisi karang dan kecenderungan pemanasan suhu permukaan di Pulau Weh. Menurut Guest et al. (2012) mendefinisikan bahwa pemutihan karang di Pulau Weh merupakan kejadian yang terparah di wilayah Asia Tenggara. Campbel et al. (2007) menilai tentang keragaman terumbu karang dan terumbu karang terkait dengan dampak tsunami dan peraturan pengelolaan sumber daya kelautan yang ada. Menurut Rudi et al. (2012) menemukan bahwa pada awal 2010, sekitar 60\% karang keras di perairan Sabang dan sekitarnya mati pasca peristiwa tsunami, yang berakibat buruk pada tangkapan nelayan (ikan karang). Banyak penelitian tentang pemutihan karang dan kaitannya terhadap isu perubahan iklim yang telah dipublikasikan (Brown \& Suharsono, 1990; Stone et al., 1999; Spillman et al., 2011; Sutthacheep et al., 2011; Marimutu et al., 2013). Akan tetapi, pengetahuan mengenai penyebab kerusakan karang di Pulau Weh belum maksimal tergali. Dengan demikian, kondisi tersebut memotivasi penelitian ini untuk mendefinisikan bahwa faktor iklim dan antropogenik memiliki pengaruh besar terhadap kerusakan karang di Pulau Weh. Oleh karena itu, pemahaman yang baik mengenai faktor iklim dan antropogenik sangat penting diketahui 
sebelum menyimpulkan bahwa kedua faktor tersebut memiliki andil dalam penurunan status kondisi karang di Pulau Weh. Tujuan penelitian ini adalah untuk mendapatkan gambaran tren kenaikan suhu permukaan selama beberapa tahun terakhir dan penyebab kerusakan karang di Pulau Weh. Hal ini penting karena studi mengenai pengaruh faktor iklim, fluktuasi suhu permukaan laut, dan penilaian kondisi terumbu karang masih jarang dilakukan di Pulau Weh.

\section{BAHAN DAN METODE}

Data suhu tahunan dalam bentuk deret waktu diunduh dari halaman website European Center for MediumRange Weather Forecast (ECMWF) halaman web (http://www.ecmwf.int/en/research/climate-reanalysis/ browse-reanalysis-datasets) dalam bentuk dari reanalisis data di wilayah $5,75-5,95^{\circ} \mathrm{N}$ dan $95,175-$ $95,425^{\circ} \mathrm{E}$ dan memiliki resolusi $0.125^{\circ}$. Data suhu perairan in situ diperoleh melalui survei langsung pada Maret-April 2017 di tiga (3) stasiun pengamatan yaitu Keunekai, Ie Meulee, dan Batee Glah (Gambar 1). Pengukuran suhu secara in situ dilakukan dengan menggunakan $H O B O$ ware di dua perairan yakni Ie Meulee dan Keunekai. Untuk perairan Batee Glah, suhu diukur menggunakan instrumen Acoustic Doppler Current Profiler (ADCP) NORTEK, alat pengukura arus laut yang juga dapat mengukur suhu perairan mulai dari 17 Maret - 4 April 2017, namun dalam hal ini hanya di ekstrak data hasil pengukuran suhunya saja. Sedangkan, data sekunder terdiri dari Dipole Mode Index terkini dan Peta Rupa Bumi Indonesia wilayah Sumatera tahun 2013 sebagai peta dasar dan citra Google Earth sebagai data pendukung.

Data suhu yang diunduh kemudian disortir dan dianalisis secara statistik, kemudian dihitung derajat pemanasan mingguan (DHW) dan rata-rata bulanan maksimum (MMM), yang menunjukkan berapa banyak tekanan panas yang terakumulasi di suatu daerah selama 12 minggu sebelumnya (3 bulan).

Survei terumbu karang dilakukan pada Bulan Maret 2017. Line Intercept Transect (LIT) digunakan untuk menentukan komunitas bentik berdasarkan bentuk kehidupan yang ditemukan. Komunitas karang dicirikan oleh kategori bentuk kehidupan yang memberi informasi tentang morfologi komunitas karang secara deskriptif. Komponen habitat dasar laut dan panjang tutupan transisi yang ditemukan sepanjang garis transek $(10 \times 10 \mathrm{~m})$ kemudian dikelompokkan berdasarkan bentuk pertumbuhannya (Mutmainah dan Clara, 2017), kriteria penutupan karang ditunjukkan pada Tabel 2. Perhitungan persen tutupan karang menggunakan rumus sebagai berikut:

persen tutupan karang $(\%)=\frac{\text { panjang bentuk hidup }(\mathrm{cm})}{\text { panjang garis transek }(\mathrm{cm})} \times 100 \%$

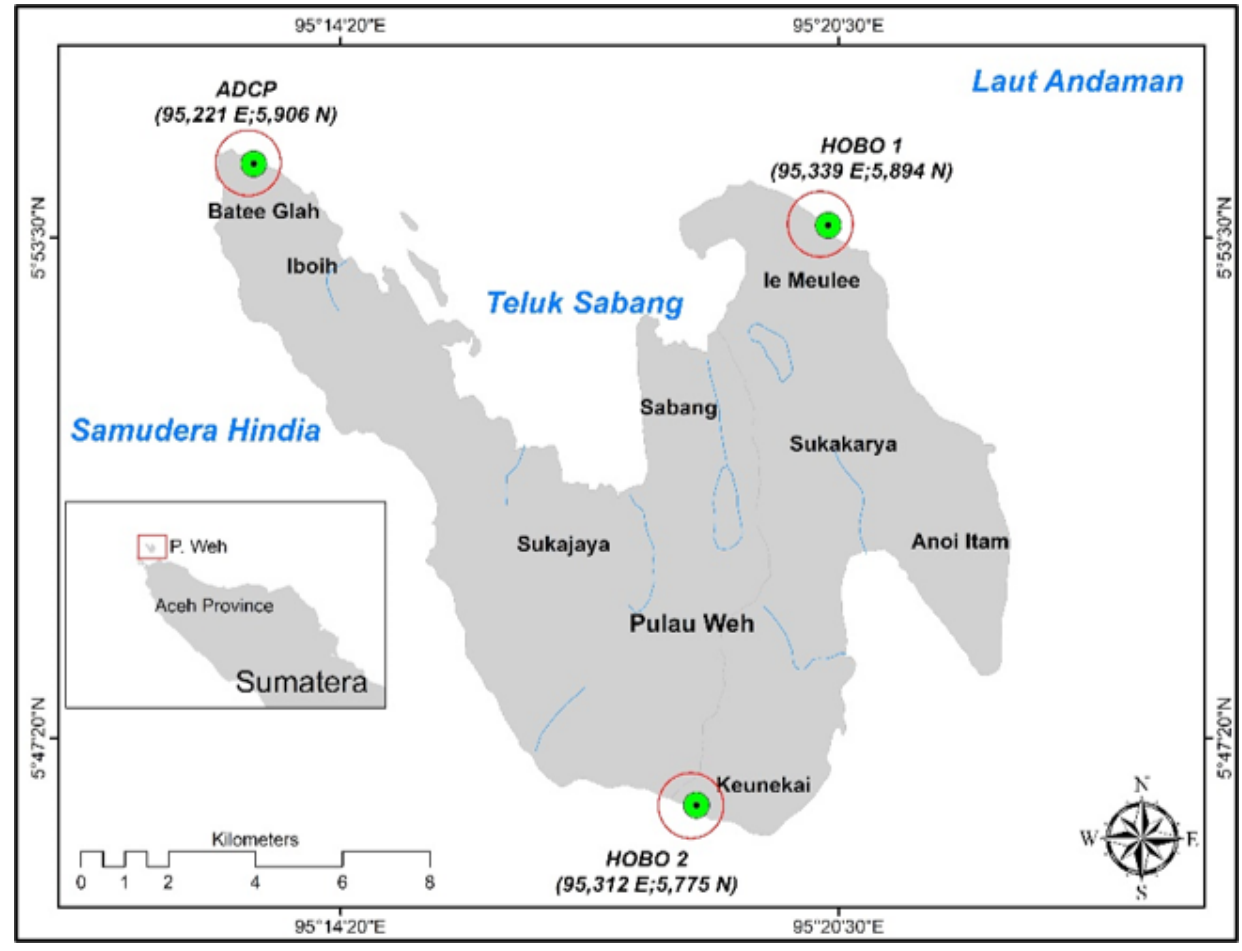

Gambar 1. Peta lokasi Penelitian.

Figure 1. Map of Research location. 
Tingkat kerusakan terkait dengan tingginya tingkat perubahan kondisi karang (karang hidup dan karang mati), rasio kematian karang dapat diketahui dengan menghitung Indeks Bleaching dan Mortality (BMI) (Puspitasari et al., 2016) dengan rumus sebagai berikut:

$$
B M I=\frac{D C+R}{L C+D C+R}
$$

$$
\begin{aligned}
& \text { dimana, } \\
& \begin{array}{ll}
\text { DC } & \text { Penutupan karang mati } \\
\text { LC } & =\text { Penutupan karang hidup } \\
\mathrm{R} & =\text { Rubble (patahan karang) }
\end{array}
\end{aligned}
$$

Nilai BMI yang mendekati 0 menggambarkan bahwa tidak ada perubahan dalam komunitas kehidupan karang, oleh karena itu jika nilai BMI mendekati 1, menjelaskan bahwa terdapat tingkat kematian yang cukup tinggi. Kategori BMI ditunjukkan dalam Tabel 1 .

\section{HASIL DAN PEMBAHASAN}

Pada Gambar 2, kondisi IOD pada Tahun 2016 didominasi oleh IOD negatif dengan DMI nilai -0,47. Hal tersebut menunjukkan bahwa kondisi SST di Samudera Hindia bagian timur harus lebih hangat dari pada kondisi normal (Saji et al., 1999). Hal ini terbukti pada Gambar 3 dan 4, terdapat anomali positif SST di Pulau Weh pada Tahun 2016. SST mencapai nilai tertinggi di Tahun 2016.

Selain itu, kondisi anomali SST di Pulau Weh dapat
Tabel 1. Kriteria persen tutupan karang

Table 1. Criteria for percent coral cover

\begin{tabular}{lll}
\hline Kategori & $\begin{array}{l}\text { Persen } \\
\text { tutupan (\%) }\end{array}$ & BMI \\
\hline Rendah & $0-24.9$ & $0-0.249$ \\
Sedang & $25-49.9$ & $0.25-0.499$ \\
Tinggi & $50-74.9$ & $0.5-0.749$ \\
Sangat tinggi & $75-100$ & $0.75-1$ \\
\hline
\end{tabular}

Sumber: Peraturan Pemerintah Kementerian Lingkungan Hidup dan Kehutanan No. 4, 2011.

diamati dari rata-rata suhu bulanan (Gambar 3), yang menunjukkan bahwa kondisi SST tertinggi terjadi pada Tahun 2016. Kondisi SST di Pulau Weh meningkat selama 5 tahun sejak 2011 hingga 2016.

Fluktuasi SST dipengaruhi oleh IOD, dapat diamati pada Gambar 2 dan 3. Kondisi IOD selama Bulan Agustus - Desember 2015 memiliki nilai tertinggi, hal ini disebut oleh IOD positif. IOD $(+)$ memicu terjadinya penurunan suhu di perairan Barat Sumatera, termasuk perairan Pulau Weh, dimana pada Agustus-Desember 2015 nilai suhu cenderung lebih rendah (Gambar 3). Pada periode berikutnya (hampir disepanjang Tahun 2016), kondisi IOD bernilai negatif (IOD (-)). Fase negatif dari IOD ini memicu peningkatan suhu secara dramatis di perairan Barat Sumatera. Suhu disepanjang Tahun 2016 mencapai nilai tertinggi bila dibandingkan dengan tahun-tahun sebelumnya (Gambar 3). Sehingga jelas bahwa potensi pemutihan dan kematian karang di Pulau Weh pada Tahun 2016 terjadi secara masal akibat dari kenaikan suhu perairan. Menurut Prabuning et al. (2017) berdasarkan survei pada Bulan Mei-Juni 2016, kasus pemutihan karang terjadi hampir disepanjang wilayah Indonesia yang berhadapan langsung dengan

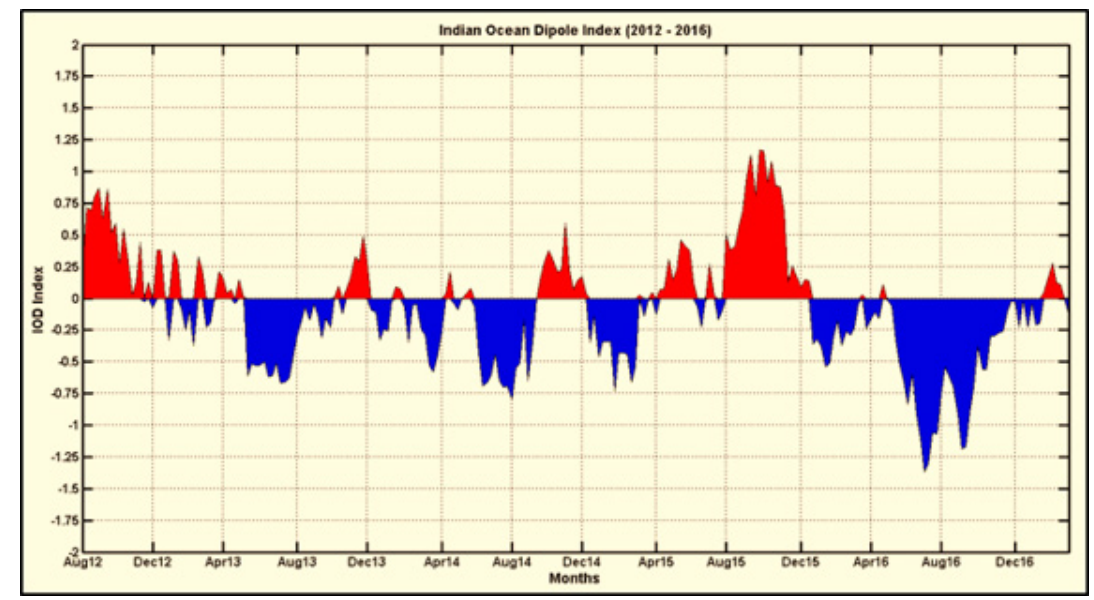

Gambar 2. Dipole Mode Index Tahun 2012-2017. (Sumber: NOAA, 2018).

Figure 2. Dipole Mode Index 2012-2017. (Source: NOAA, 2018). 


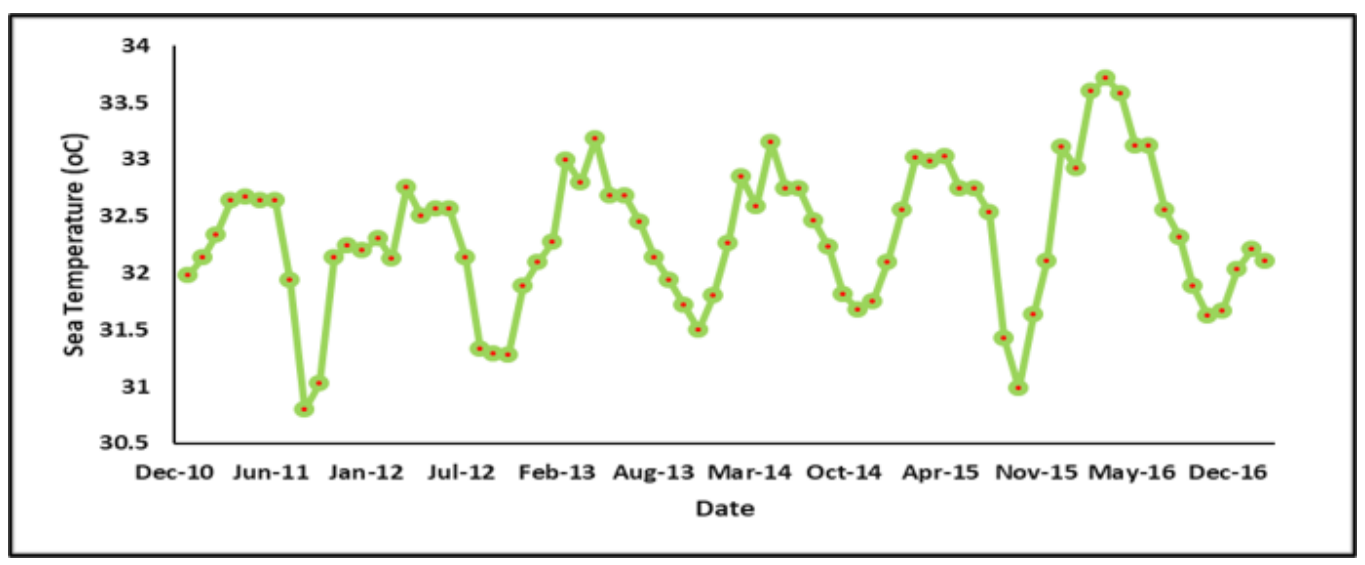

Gambar 3. Rata-rata suhu bulanan selama 6 tahun. (Sumber: ECMWF, 2018).

Figure 3. Rata-rata suhu bulanan selama 6 tahun. (Sumber: ECMWF, 2018).

Samudera Hindia (dari Pulau Weh hingga Maluku) dengan persentase pemutihan $\pm 50 \%$. Pemutihan karang pada Tahun 2016 dipicu oleh kenaikan suhu permukaan air laut akibat dari pengaruh iklim.

Selama lebih dari 5 tahun, rata-rata bulanan fluktuasi SST memiliki pola yang hampir sama (Gambar 3), hanya nilainya saja yang berbeda pada tiap tahunnya tergantung dari kondisi DMI. Pada musim basah (November, Desember, Januari) SST relatif lebih rendah daripada musim panas (Mei, Jun, Jul), menurut Vinayachandran et al. (2009), IOD merubah kondisi perairan barat Sumatera menjadi lebih hangat selama Bulan Mei dan Juli, fluks pemanasan di permukaan dan adveksi horizontal disebabkan oleh SST (anomali) dan kontribusi yang terakhir menurun setelah Bulan Agustus.

Nilai SST yang tertinggi ditemukan pada pertengahan Tahun 2013, 2014, dan maksimal pada Tahun 2016 dimana status DMI dominan positif pada periodeperiode tersebut. Nilai SST menurun secara signifikan pada Tahun 2015 dimana DMI bernilai positif hampir disepanjang tahun (Gambar 3 dan 4). Hal tersebut menunjukkan bahwa kondisi IOD menjadi faktor utama yang mempengaruhi suhu di perairan. Kejadian IOD juga berpengaruh terhadap peningkatan curah hujan dan fluktuasi anomali suhu perairan (Kripalani et al., 2010).

Nilai suhu berkisar antara $30,8-33,8^{\circ} \mathrm{C}$ dan naik hingga $\pm 3^{\circ} \mathrm{C}$ antara Tahun 2015 dan 2016, jelas bahwa kondisi tersebut adalah pemicu kejadian bleaching di Pulau Weh secara regional. Karang dapat tumbuh dengan baik atau optimal dilaut tropis pada suhu $28-29^{\circ} \mathrm{C}$. Bila terjadi kenaikan suhu $2-3^{\circ} \mathrm{C}$ diatas atau dibawah normal dalam kurun waktu 1-2 minggu maka karang akan menunjukkan tanda-tanda terjadinya bleaching. Bila suhu naik atau turun berlanjut hingga satu bulan maka seluruh koloni karang, karang lunak, anemone, dan zoanthid akan memutih dan akan mengalami kematian (Anonim, 2016). Menurut Vinayachandran et al. (2009) selama kejadian IOD negatif, produktivitas primer diwilayah timur Samudera Hindia menurun dan memicu kematian karang pada wilayah yang lebih luas.

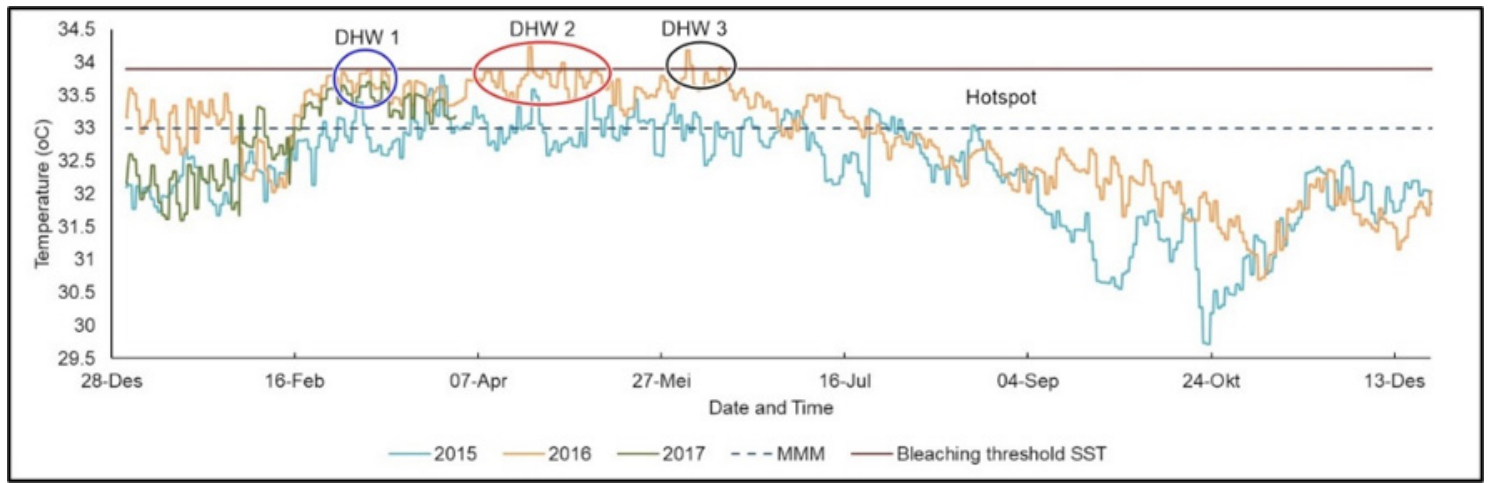

Gambar 4. Perbandingan nilai suhu 3 tahun terakhir dan identifikasi bleaching di Pulau Weh.

Figure 4. Comparison of the last 3 years' temperature values and bleaching identification on Pulau Weh. 


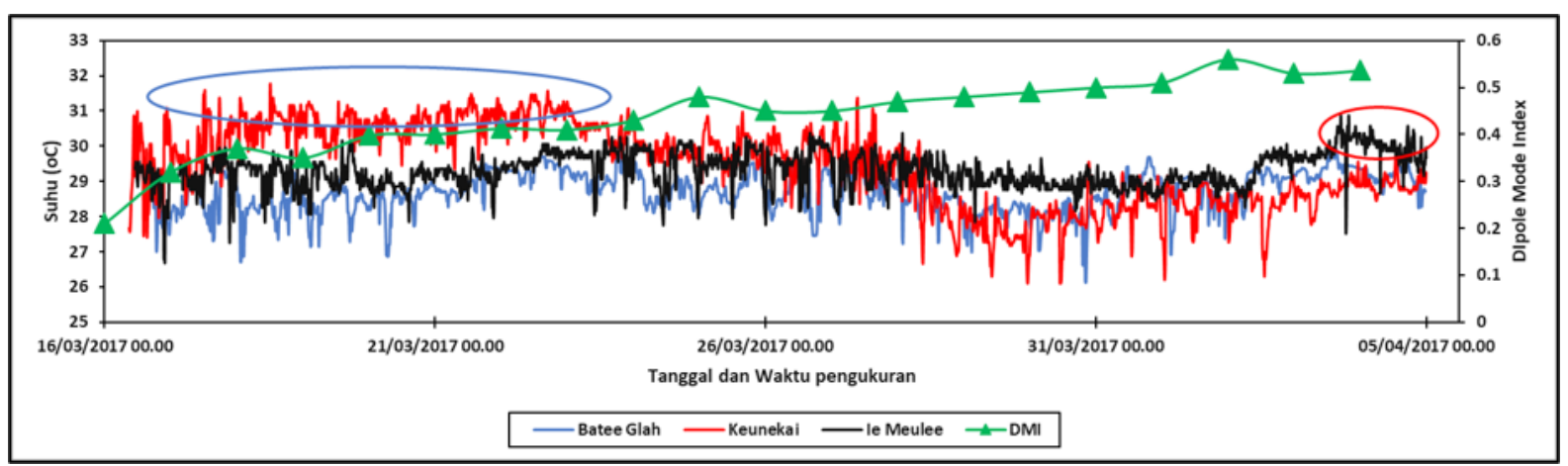

Gambar 5. Fluktuasi suhu perairan Batee Glah (garis biru), Keunekai (garis merah), dan Ie Meulee (garis hitam) selama 1 bulan pengukuran (17 maret - 4 April 2017) secara In Situ yang dibandingkan dengan kondisi Dipole mode harian (garis hijau).

Figure 5. Fluctuations in the temperature of Batee Glah waters (blue line), Keunekai (red lines), and Ie Meulee (black lines) for 1 month of measurement (March 17 - April 4, 2017) in In Situ compared to daily Dipole mode conditions (green line).

Gambar 4 menunjukkan perbandingan suhu dalam 3 tahun terakhir, dengan nilai rata-rata bulanan maksimum (MMM) sebesar $33^{\circ} \mathrm{C}$ dan derajat pemanasan bulanan sebesar $33,8^{\circ} \mathrm{C}$. Fluktuasi suhu pada Tahun 2015 (garis biru) mencapai titik pemanasan (hotspot) pada musim peralihan I hingga musim timur. Pada Tahun 2016 ditemukan bahwa kenaikan suhu telah mencapai batas tertinggi pemicu bleaching yang terjadi pada Bulan Maret (DHW 1), April (DHW 2), dan Juni (DHW 3), sehingga jelas bahwa bleaching dalam regional luas terjadi pada Tahun 2016. Pada awal Tahun 2017 kondisi bleaching tidak terlalu parah karena fluktuasi suhu hanya mencapai titik pemanasan pada Bulan Maret. Menurut Wouthuyzen et al. (2015) nilai suhu pada titik pemanasan yang meningkat $>1^{\circ} \mathrm{C}$ dan diikuti oleh nilai $\mathrm{DHW}<4^{\circ} \mathrm{C}$ menandakan bahwa terjadi tekanan suhu terhadap karang.

SST di perairan Batee Glah dimana merupakan stasiun pengamatan terdekat dengan Samudra Hindia memiliki nilai suhu berkisar antara $26,1-29,8^{\circ} \mathrm{C}$. Fluktuasi suhu di perairan Batee Glah tergolong stabil dan normal pada Maret-April 2017 (Gambar 5). Pada periode tersebut nilai DMI berkisar antara 0-0,57 (IOD positif), sehingga tidak memicu tekanan suhu terhadap karang. Menurut Purbani et al. (2014), suhu di perairan Pulau Rubiah dan sekitarnya berkisar antara $28,4-29,7^{\circ} \mathrm{C}$. SST di perairan Ie Meulee berkisar antara $26,2-31^{\circ} \mathrm{C}$. Terjadi kenaikan suhu sebesar $\pm 1^{\circ} \mathrm{C}$ pada 4 April 2017 (lingkaran merah) (Gambar 5). Kenaikan suhu secara tiba-tiba tersebut lebih besar kemungkinan dipengaruhi oleh faktor eksternal dari darat maupun pengaruh kondisi iklim samudera (IOD dan ENSO).

Pada stasiun Keunekai suhu berkisar antara $25,5-31,8^{\circ} \mathrm{C}$ (Gambar 5) yang merupakan fluktuasi suhu dengan perubahan yang cukup signifikan selama pengukuran di lapangan. Perairan Keunekai merupakan salah satu perairan yang berbatasan langsung dengan Samudera Hindia, dimana interaksi laut dan atmosfer menjadi faktor utama yang mempengaruhi suhu di kawasan ini. Kombinasi dua osilasi iklim yakni ENSO dan IOD memainkan peran besar dalam perubahan suhu perairan. Perairan Keunekai merupakan wilayah habitat terumbu karang yang paling rusak di Pulau Weh. Selain karena pengaruh kondisi iklim Samudera Hindia, kerusakan karang terutama terjadi karena penggunaan alat tangkap yang tidak ramah lingkungan, walauypun dalam skala kecil karang diwilayah tersebut menjadi rusak dan mati, sehingga menghasilkan wilayah ekosistem perairan yang tidak stabil dan perlu dilakukan rehabilitasi.

Secara umum, banyak faktor yang mempengaruhi fluktuasi suhu muka laut di Pulau Weh selain IOD. Walaupun IOD memiliki peran besar dalam pengaruhnya terhadap intensitas hujan dan periode musim kering, namun Fenomena El-Nino Southern Oscillation (ENSO) yang terjadi sepanjang tahun 2016 menjadi faktor utama terjadinya pemutihan massal di Perairan Barat Sumatera (Wisha \& Khoirunnisa, 2017). Fenomena ENSO menyebabkan pengalihan sirkulasi udara antara Samudera Hindia dan Pasifik terutama pada pergantian dari musim basah ke musim kering dan sebaliknya yang berdampak pada peningkatan kenaikan muka air laut, suhu muka laut, perubahan pola curah hujan, intensitas kejadian cuaca ekstrim, dan ketersediaan air (Heryati et al., 2018).

Variabilitas suhu dan salinitas di Samudera Hindia dipengaruhi oleh musim, ENSO, dan IOD dimana distribusi variabilitas secara horizontal dipengaruhi oleh aliran massa air yang berasal dari Barat Sumatera dan 


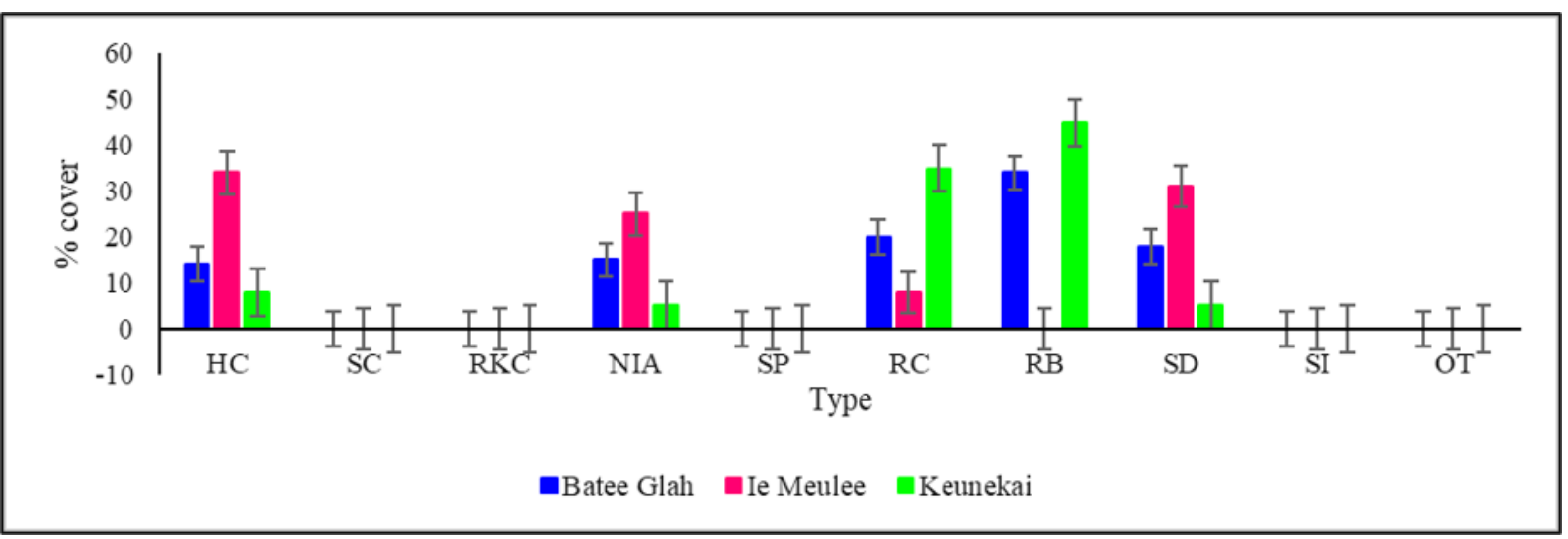

Gambar 6. Persen tutupan karang pada setiap stasiun pengamatan. HC (hard coral), SC (soft coral), RKC (recently killed coral), NIA (nutrient indicator algae), SP (Sponge), RC (Rock), RB (Rubble), SD (Sand), dan OT (Other).

Figure 6. Percent of coral cover at each observation station. HC (hard coral), SC (soft coral), RKC (recently killed coral), NIA (nutrient indicator algae), SP (Sponge), RC (Rock), RB (Rubble), SD (Sand), and OT (Other).

beberapa gerbang arus lintas Indonesia (ARLINDO) (Wardani et al., 2014). Distribusi anomali suhu dipicu oleh aliran South Equatorial Current (SEC) yang sangat kuat terjadi pada awal musim timur (Utamy et al., 2015; Purba et al. (2018), hal tersebut sesuai dengan data suhu pada awal musim timur 2016 (Gambar 3) yang mencapai $34^{\circ} \mathrm{C}$ yang sangat berpotensi memicu pemutihan karang.

Stasiun Batee Glah merupakan lokasi pengamatan yang terletak di bagian utara Pulau Weh (Sabang) dan mendapatkan pengaruh cukup kuat dari perairan Samudra Hindia. Bentuk pertumbuhan organisme bentik di wilayah ini cukup beragam dan rapat. Hasil perhitungan terhadap persentase penutupan karang keras mendapatkan persentase tutupan karang berkisar $14,7 \%$. Adapun bentuk hidup karang keras yang dominan ditemukan di stasiun ini adalah Acropora Tabulate (ACT), Coral Foliose (CF) dan Coral Massive (CM) (Gambar 6). Pada kawasan ini tipe pantai yang pada umumnya berbatu, sangat kokoh dan terjal. Hal ini sangat berbeda dengan pantai di kawasan Keunekai dan Ie Meulee. Kontruksi pantai berbatu-batu besar ini diperkirakan akan melindungi garis pantai. Sementara itu arus balik permukaan yang kembali ke laut juga sangat sedikit membawa material atau sedimen yang akan merusak terumbu karang. Kerusakan karang di wilayah ini dipengaruhi oleh kondisi oseanografi di Samudera Hindia, termasuk transport sedimen yang mengancam ekosistem terumbu karang diwilayah ini. Menurut Munasik et al. (2006) pola arus mempengaruhi distribusi sedimen tersuspensi dan memiliki peran besar terhadap mekanisme turbulensi sedimen yang meningkatkan kekeruhan perairan yang dapat mengganggu pertumbuhan dan kelangsungan hidup karang.

Daerah Ie Meulee yang terletak pada bagian utara Pulau Weh (Sabang) yang cukup terbuka terhadap pengaruh arus dan gelombang dari Laut Andaman, terutama pada puncak musim barat dan musim timur (Gibson et al., 2007). Bentuk pertumbuhan karang dominan ditemukan di lokasi ini adalah karang masive yang diperkirakan akibat adanya pengaruh aksi gelombang yang kuat. Hasil pengamatan juga memperlihatkan bahwa komponen abiotik terutama SD dan RB yang sangat dominan. Dengan cukup tingginya pesentase NIA, tutupan karang di Ie Meulee termasuk dalam katergori sedang, dengan persentase karang keras (HC) mencapai $35 \%$ (Gambar 6).

Pada kawasan terumbu karang di perairan Keuneukai dikatakan buruk dan hanya mencapai 9,1 \% tutupan karang keras (HC). Secara umum perairan Keunekai didominasi oleh tumpukan karang mati (RB) dengan persen tutupan mencapai $45 \%$ dan batuan (RC) dengan persentase mencapai $35 \%$ (Gambar 6). Selain pengaruh dari kondisi iklim yang berdampak pada peningkatan suhu secara signifikan, buruknya kondisi tutupan karang di Keunekai dipengaruhi oleh pencemaran nutrien yang menyebabkan siklus biogeokimia di perairan terganggu (Wisha et al., 2018; Wisha \& Ondara, 2018).

Faktor iklim yang cukup fluktuatif dan sosial budaya masyarakat di Pulau Weh mengakibatkan terjadinya peningkatan kematian karang, pada stasiun Keunekai dan Batee Glah nilai BMI dikategorikan dalam kematian karang yang sangat tinggi (Tabel 2). Berbeda dengan stasiun Ie Meulee yang dikategorikan dalam 
kematian karang yang sangat rendah. Persen tutupan karang berkisar antara 9,1-34,4 \%, yang termasuk dalam kategori tutupan karang rendah hingga sedang. Berdasarkan penelitian sebelumnya oleh Purbani et al. (2014) tutupan karang di perairan Pulau Weh (Pulau Rubiah dan sekitarnya) berkisar antara 15,14-54,26\% dalam kategori sedang hingga baik pada Tahun 2009 dan berkisar antara 11,24-64,81\% pada Tahun 2004.

Gambar 7 menunjukkan kondisi terumbu karang terkini di tiga lokasi pengamatan. Diwilayah Batee Glah didominasi oleh karang massive dan branching, ditemukan gejala pemutihan karang dan karang mati, wilayah ini merupakan daerah difraksi gelombang sehingga kecepatan arus dan mekanisme transport sangat dinamis. Kondisi terumbu karang di Ie Meulee merupakan yang paling baik diantara stasiun pengamatan lainnya, populasi ikan karang juga sangat melimpah di wilayah ini. Di perairan Keunekai didominasi oleh karang jenis Acropora, bersubstrat pasir dan merupakan wilayah ekosistem terumbu karang yang sangat memprihatinkan. Menurut Helpern et al. (2008) banyak aktifitas yang berdampak pada perubahan lingkungan perairan, dampak komulatif sangat perlu dikendalikan untuk mengurangi efek jangka panjang yang akan terjadi.

\section{KESIMPULAN DAN SARAN}

Tren suhu permukaan laut (SST) selama Tahun 20112017 sangat fluktuatif. Fluktuasi suhu permukaan berkisar $\pm 3^{\circ} \mathrm{C}$. Hal tersebut dipengaruhi oleh dominasi kejadian IOD yang memicu naik turunnya suhu di perairan barat Sumatera. Suhu yang meningkat

Tabel 2. Dokumentasi hasil survei karang di 3 stasiun pengamatan Table 2. Documentation of coral survey results in 3 observation stations

\begin{tabular}{lllllll}
\hline Stasiun & \multicolumn{2}{c}{$\begin{array}{c}\text { Karang Karang Biota } \\
\text { hidup }\end{array}$} & mati & $\begin{array}{l}\text { Algae } \\
\text { lain }\end{array}$ & $\begin{array}{l}\text { Komponen } \\
\text { abiotik }\end{array}$ & BMI \\
\cline { 2 - 6 } & \multicolumn{7}{c}{$\%$} & & \\
\hline Keunekai & 9,1 & 43,5 & - & 6,2 & 41,2 & 0,82 \\
Ie Meulee & 34,4 & 1,3 & - & 25,4 & 39,9 & 0,03 \\
Batee Glah & 14,7 & 34,4 & - & 15,3 & 35,6 & 0,7 \\
& & & & & \\
\hline
\end{tabular}
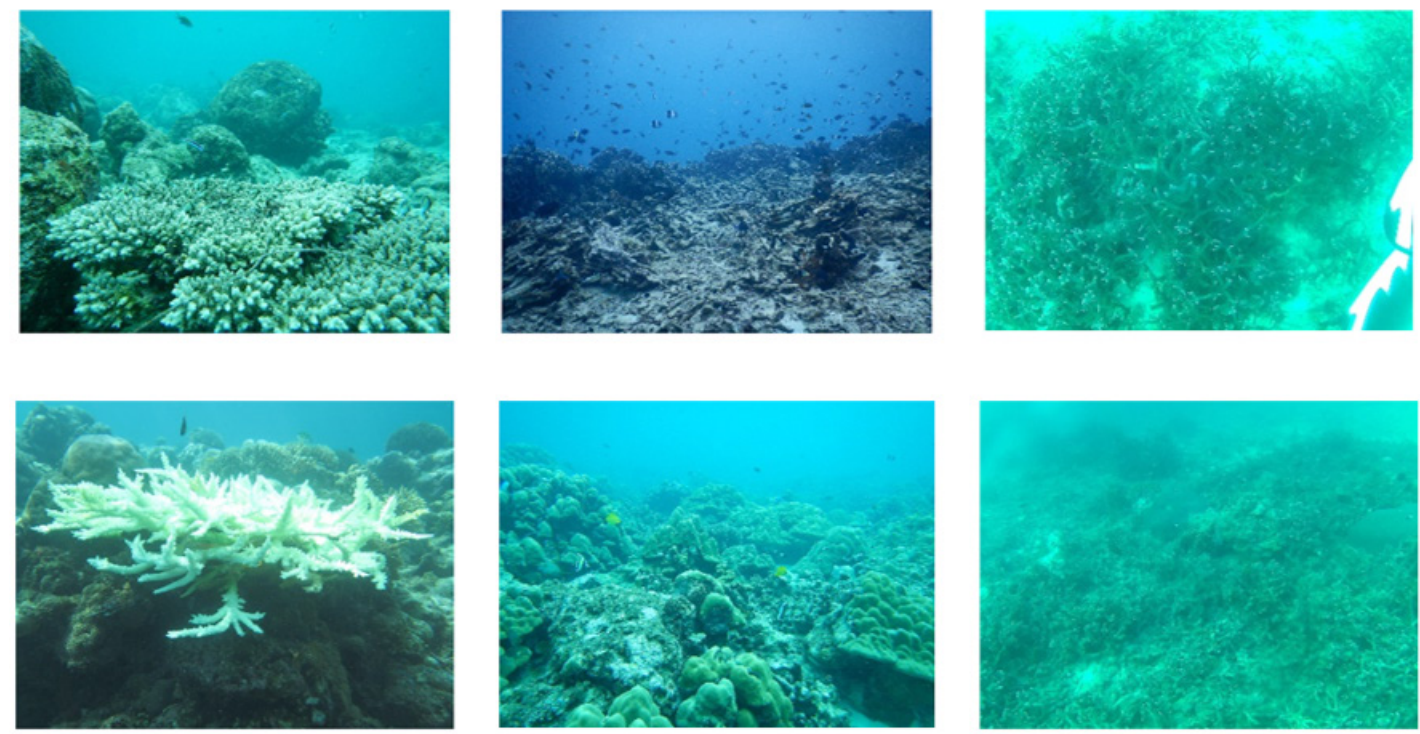

Gambar 7. Dokumentasi hasil survei karang di 3 stasiun pengamatan : a) Kondisi ekosistem karang di Batee Glah, b) Sampel pemutihan karang di Batee Glah, c) Kondisi karang mati dan patah di Ie Meulee, d) Di perairan Ie Meulee didominasi oleh karang massive, e) Perairan Keunekai didominasi oleh jenis Acropora sp, f) Banyak teridentifikasi patahan karang di Keunekai.

Figure 7. Documentation of coral survey results in 3 observation stations: a) Condition of coral ecosystem in Batee Glah, b) Samples of coral bleaching in Batee Glah, c) Condition of dead and broken corals in Ie Meulee, d) In Ie Meulee waters dominated by massive corals, e) Keunekai waters are dominated by Acropora sp, f) Many coral fractures have been identified in Keunekai.

JURNAL KELAUTAN NASIONAL, Vol. 14, No 2, Agustus 2019, Hal. 103-112 
mempengaruhi pemutihan karang, menghasilkan nilai tutupan karang yang rendah dan angka kematian karang yang tinggi. Perlu dilakukan rehabilitasi ekosistem perairan, terutama di perairan Keunekai. Kerusakan terumbu karang diperairan Keunekai juga disebabkan oleh penggunaan alat tangkap yang tidak ramah ligkungan.

Studi ini hanya membahas dampak fluktuasi suhu dan masalah sosial budaya masyarakat setempat terhadap fenomena kerusakan karang. Sebenarnya, faktor utama yang juga berpengaruh tehadap kondisi karang adalah pengasaman dan pencemaran laut. Untuk penelitian selanjutnya disarankan agar parameter tersebut dapat dianalisis. Studi ini juga memberikan informasi penting kepada masyarakat untuk mengurangi efek rumah kaca dan pemanasan global untuk mengendalikan perubahan iklim, walaupun hal tersebut tidak dapat dihindarkan.

\section{UCAPAN TERIMA KASIH}

Ucapan terimakasih disampaikan kepada Loka Riset Sumber Daya dan Kerentanan Pesisir (LRSDKP) atas DIPA anggaran riset Pulau Weh 2017, kepada ECMWF yang telah menyajikan data realtime suhu permukaan laut, dan pihak-pihak yang membantu dalam penyelesaian artikel ini.

\section{DAFTAR PUSTAKA}

Anonim. (2016). Pemutihan Karang (Bleaching Coral) dan Kejadian Bleaching Tahun 2016. CRITC COREMAP-Lembaga Ilmu Pengetahuan Indonesia (LIPI). Halaman Web (http://coremap.or.id/ berita/1172). Diakses pada tanggal 23 November 2017 pukul 16.08 WIB.

Baird, A. H., Bhagooli, R., Ralph, P. J., \& Takahashi, S. (2009). Coral bleaching: the role of the host. Trends in Ecology \& Evolution, 24(1), 16-20. https://doi. org/10.1016/j.tree.2008.09.005.

Burke, L., Selig, E., \& Spalding, M. (2006). Reefs at risk in Southeast Asia.

d Resources Institute (WRI), Washington D.C., USA, pp 76.

Campbell, S. J., Pratchett, M. S., Anggoro, A. W., Ardiwijaya, R. L., Fadli, N., Herdiana, Y., Kartawijaya, K., Tasrif, T., Mahyiddin, M., Dodent, D., Mukminin, M., Ahmad, A., Pardede, P., Shinta, T., Rudi, E. S., Achris, M., \& Baird, A. H. (2007). Disturbance to coral reefs in Aceh, Northern Sumatra: impacts of the SumatraAndaman tsunami and pre-tsunami degradation. Atoll Research Bulletin, 544, 55-78.

Du, Y., Qu, T., \& Meyers, G. (2008). Interannual variability of sea surface temperature off Java and Sumatra in a global GCM. Journal of Climate, 21(11), 2451-2465. https://doi.org/10.1175/2007jcli1753.1.

ECMWF. (2017). Forecast Chart and Data. Diunduh pada halaman web: https://www.ecmwf.int/en/forecasts, pada tanggal 21 November 2017 Pukul 12.34 WIB.

Gibson, R. N., Atkinson, R. J. A., \& Gordon, J. D. M. (2007). Coral reefs of the Andaman Sea - an integrated perspective. Oceanography and marine biology: an annual review, 45, 173-194.

Guest, J. R., Baird, A. H., Maynard, J. A., Muttaqin, E., Edwards, A. J., Campbell, S. J., Yewdall, K., Affendi, Y. A., \& Chou, L. M. (2012). Contrasting patterns of coral bleaching susceptibility in 2010 suggest an adaptive response to thermal stress. PloS one, 7(3), e33353. https://doi.org/10.1371/journal. pone. 0033353 .

Halpern, B. S., Walbridge, S., Selkoe, K. A., Kappel, C. V., Micheli, F., D'agrosa, C., Bruno, J. F., Casey, K. S., Ebert, C., Fox, H. E., Fujita, R., Heinemann, D., Lenihan, H. S., Madin, E. M. P., Perry, M. T., Selig, E. R., Spalding, M., Steneck, R., \& Watson, R. (2008). A global map of human impact on marine ecosystems. Science, 319(5865), 948-952. https://doi.org/10.1126/ science. 1149345.

Hagan, A. B., Foster, R., Perera, N., Gunawan, C. A., Silaban, I., Yaha, Y., Manuputy, Y., Hazam, I., \& Hodgson, G. (2007). Tsunami impacts in Aceh Province and North Sumatra, Indonesia. Atoll Research Bulletin, 544, $37-$ 54.

Heryati, H., Pranowo, W. S., Purba, N. P., Rizal, A., \& Yuliadi, L. P. S. (2018). Java Sea Surface Temperature Variability during ENSO 1997-1998 and 20142015. Omni-Akuatika, 14(1), 96-107. http://dx.doi. org/10.20884/1.oa.2018.14.1.429.

Kripalani, R. H., Oh, J. H., \& Chaudhari, H. S. (2010). Delayed influence of the Indian Ocean Dipole mode on the East Asia-West Pacific monsoon: possible mechanism. International Journal of Climatology, 30(2), 197-209. https://doi.org/10.1002/joc.1890.

McWilliams, J. P., Côté, I. M., Gill, J. A., Sutherland, W. J., \& Watkinson, A. R. (2005). Accelerating impacts of temperature-induced coral bleaching in the Caribbean. Ecology, 86(8), 2055-2060. https://doi. org/10.1890/04-1657.

Munasik, M., Sugianto, D. N., Pranowo, W. S., Suharsono, S., Situmorang, J., \& Kamiso, H. N. (2006). Pola Arus dan Kelimpahan Karang Pocillopora damicornis di Pulau Panjang, Jawa Tengah. ILMU KELAUTAN: Indonesian Journal of Marine Sciences, 11(1), 11-18. https://doi.org/10.14710/ik.ijms.11.1.11-18.

NOAA. (2017). Download Climate Time Series - Dipole Mode Index. Diunduh pada halaman web: https:// www.esrl.noaa.gov/psd/gcos wgsp/Timeseries/Data/ dmi.long.data pada tanggal 27 November 2017 Pukul 12.29 WIB.

Prabuning, D., Agung, F., Pattinaja, Y., Yoga, H., Setyo, N., Subhan, B., Yudiarso, P., Abrar, M., dan Ardiwijaya, R. (2017). Status Pemutihan Karang Akibat Meningkatnya Suhu Permukaan Air Laut di Indonesia 
Tahun 2016. Dipresentasikan dalam Simposium Nasional Konservasi Perairan Pesisir dan PulauPulau Kecil 2017. 9-10 Mei 2017, Jakarta, Indonesia. Purba, N. P., Pranowo, W. S., Faizal, I., \& Adiwira, H. (2018). Temperature-Salinity stratification in the Eastern Indian Ocean using argo float. In IOP Conference Series: Earth and Environmental Science, 162(1), 012010. IOP Publishing. https://doi. org/10.1088/1755-1315/162/1/012010.

Purbani, D., Kepel, T. L., \& Takwir, A. (2014). Kondisi Terumbu Karang Di Pulau Weh Pasca Bencana Mega Tsunami. J. Manusia dan Lingkungan, 21(3), 331340. https://doi.org/10.22146/jml.18561.

Puspitasari, A. T. T., Amron, A., \& Alisyahbana, S. (2016). Struktur Komunitas Karang Berdasarkan Karakteristik Perairan di Taman Wisata Perairan (TWP) Kepulauan Anambas. Omni-Akuatika, 12(1), 55-72. https://doi.org/10.20884/1.oa.2016.12.1.30.

Rudi, E., Iskandar, T., Fadli, N., \& Hidayati, H. (2012). Impact of mass coral bleaching on reef fish community and fishermen catches at Sabang, Aceh Province, Indonesia. Aquaculture, Aquarium, Conservation \& Legislation-International Journal of the Bioflux Society (AACL Bioflux), 5(5), 309-320.

Saji, N. H., Goswami, B. N., Vinayachandran, P. N., \& Yamagata, T. (1999). A dipole mode in the tropical Indian Ocean. Nature, 401(6751), 360-363. https:// doi.org/10.1038/43854.

Schott, F. A., Xie, S. P., \& McCreary, J. P. (2009). Indian Ocean circulation and climate variability. Reviews of Geophysics, 47(1), RG1002. https://doi. org/10.1029/2007rg000245.

Utamy, R. M., Purba, N. P., Pranowo, W. S., \& Suherman, H. (2015). The Pattern of South Equatorial Curent and Primary Productivity in South Java Seas. International Proceedings of Chemical, Biological, and Envrionmental Engineering, Vol, 90 (2015). https://doi.org/10.7763/IPCBEE.2015.V90.24.

Wisha, U. J., Al Tanto, T., \& Ilham, I. (2017). Spatial Distribution of Sea Surface Temperature in West Sumatera Seawaters Associated with Indian Ocean Dipole (IOD) Event in Transitional Seasons (AugustOctober) (Case Study: Pasumpahan and Sibonta Island). Jurnal Ilmiah Geomatika, 22(1), 21-28. https://doi.org/10.24895/jig.2016.22-1.459.

Yamagata, T., Lizuka, S., \& Matsura, T. (2000). Successful Reproduction of the Dipole Mode Phenomenon in the Indian Ocean Using a Model-Advance toward the Prediction of Climate Change. Geophysical Research Letter, 27(20), 3369-3372.

Yuan, Y., Chan, C. J., Zhou, W., \& Li, C. (2008). Decadal and interannual variability of the Indian Ocean Dipole. Advances in Atmospheric Sciences, 25(5), 856-866. https://doi.org/10.1007/s00376-008-0856-0.

Vinayachandran, P. N., Francis, P. A., \& Rao, S. A. (2009). Indian Ocean dipole: processes and impacts. Current trends in science, 569-589.

Wardani, R., Pranowo, W. S., \& Indrayanti, E. (2014).
Variabilitas Salinitas Berkaitan dengan ENSO dan IOD di Samudera Hindia (Selatan Jawa hingga Selatan Nusa Tenggara Periode Tahun 2004-2010). Jurnal Harpodon Borneo, 7(1), 9-18.

Wisha, U. J., \& Khoirunnisa, H. (2017). Sea Surface Temperature Rising Trend and Its Influence on the Coral Mortality in Pagai Strait, Mentawai Islands, Indonesia. International Journal of Civil Enggineering and Technology (IJCIET), 8(10), 725734.

Wisha, U. J., Ondara, K., \& Ilham, I. (2018). The Influence of Nutrient ( $\mathrm{N}$ and $\mathrm{P}$ ) Enrichment and Ratios on Phytoplankton Abundance in Keunekai Waters, Weh Island, Indonesia. Makara Journal of Science, 187197. https://doi.org/10.7454/mss.v22i4.9786.

Wisha, U. J., \& Ondara, K. (2018, December). Total organic carbon and dissolved organic nitrogen in the upper water column of Keunekai Waters, Weh Island, Indonesia: an overview of mass coral mortality impacts. In IOP Conference Series: Earth and Environmental Science, 216(1), 012037). IOP Publishing. https://doi. org/10.1088/1755-1315/216/1/012037.

Wouthuyzen, S., Abrar, M., \& Lorwens, J. (2015). Coral Bleaching Incidents of 2010 in Indonesian Waters Revealed Through Analysis of Sea Surface Temperature. Oseanologi dan Lymnologi di Indonesia, 1(3), 305-327. 